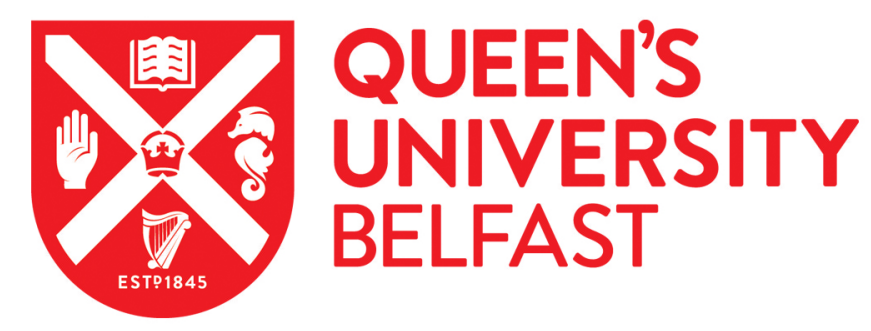

\title{
Full steam ahead or dead in the water? European Union environmental policy after the economic crisis
}

Gravey, V., \& Moore, B. (2018). Full steam ahead or dead in the water? European Union environmental policy after the economic crisis. In C. Burns, S. Sewerin, \& P. Tobin (Eds.), The Impact of the Economic Crisis on European Environmental Policy Oxford University Press.

Published in:

The Impact of the Economic Crisis on European Environmental Policy

Document Version:

Peer reviewed version

Queen's University Belfast - Research Portal:

Link to publication record in Queen's University Belfast Research Portal

Publisher rights

Copyright 2018 OUP. This work is made available online in accordance with the publisher's policies. Please refer to any applicable terms of use of the publisher.

\section{General rights}

Copyright for the publications made accessible via the Queen's University Belfast Research Portal is retained by the author(s) and / or other copyright owners and it is a condition of accessing these publications that users recognise and abide by the legal requirements associated with these rights.

Take down policy

The Research Portal is Queen's institutional repository that provides access to Queen's research output. Every effort has been made to ensure that content in the Research Portal does not infringe any person's rights, or applicable UK laws. If you discover content in the Research Portal that you believe breaches copyright or violates any law, please contact openaccess@qub.ac.uk. 


\title{
Full steam ahead or dead in the water? European Union environmental policy after the economic crisis
}

\author{
Viviane Gravey $^{1}$ and Brendan Moore ${ }^{2}$ \\ ${ }^{1}$ Queen's University Belfast \\ ${ }^{2}$ Tyndall Centre for Climate Change Research, University of East Anglia
}

\section{Introduction}

Over the last forty years, the European Union (EU) has developed one of the most comprehensive and ambitious bodies of environmental legislation in the world (Haigh, 2016; Jordan and Adelle, 2013). There are currently over $400 \mathrm{EU}$ environmental policies addressing topics as diverse as biodiversity, water quality, climate change, and agriculture (Delreux and Happaerts, 2016: 13). Yet EU environmental policy has also been the repeated target of dismantling attempts (i.e. attempts to cut, diminish or remove existing policies, see Jordan et al., 2013). Since 2008, these dismantling attempts have occurred in the context of a "conglomerate of crises" facing the EU, ranging from the economic crisis which began in 2008, the related Eurozone crisis, the refugee crisis across the Mediterranean, and the British vote to leave the EU in June 2016 (Falkner, 2016). These crises have led to an EU-wide push for austerity (Gravey, 2014), reinforced a preexisting focus on the reduction of administrative and regulatory burdens under the Better Regulation programs (Actal et al., 2011; Van den Abeele, 2010), and influenced attempts to refocus EU policy to be "big on big things and smaller on smaller things" (Barroso, 2013: 9). As a result, some have argued that environmental policy-making in the EU is losing priority, with existing environmental legislation at risk of being dismantled as part of a push for business competitiveness (Čavoški, 2015; Potočnik, 2012; Gravey, 2016).

In this context, there is a growing literature which analyses the ambition of EU environmental policy over the last 20 years, investigating issues pertaining to enlargement (Burns, 2013), better regulation (Gravey and Jordan, 2016), and austerity (Slominski, 2016). Two key questions are currently debated within this literature. First, how do austerity and the "conglomerate of crises" impact EU environmental policies: do they only affect policy discourses or do they also lead to concrete policy change? If policy change is evident, is it attributable to the weakening of existing policies (policy dismantling) or to a 
reduction in the adoption of new policies (Steinebach and Knill, 2016)? Second, are environmental policy subsectors affected differently (Kassim et al., 2017)? In particular is EU climate and energy policy insulated from the dismantling pressures that have been brought to bear on more traditional EU environmental policies (Slominski, 2016)?

One important finding in the current literature is that EU environmental policy shows little significant signs of dismantling, despite concerted attempts to do so over the years. Taking into consideration a wide array of environmental policy sectors (e.g., waste, biodiversity, and water), Gravey and Jordan (2016) found evidence of some policy dismantling. However, in most cases the overall piece of legislation remained intact, with the rare dismantling events occurring largely at the level of policy instruments and regulatory standards. Overall, they found no major cuts to EU policies; instead certain elements were weakened while others were strengthened. Studying changes to EU air and water policies, Steinebach and Knill (2016) found little evidence of policy dismantling - but instead a sharp drop in the number of new policy proposals by the European Commission under José Manuel Barroso between 2004 and 2014. This finding was echoed by Kassim et al. (2017), who found the decrease in Commission policy proposals was not limited to environmental policy but concerned other policy sectors as well. As for climate and energy policy, Slominski (2016) argued that the economic crisis negatively impacted policy discourses and ambition but not policy content. In contrast, Burns and Tobin (2016) found that although the number of EU climate policies had increased since the start of the economic crisis, the ambition of new proposals had decreased. However, they did not find outright dismantling.

To explore this topic, one approach is to compare subsectors using measures of policy intensity: how strict or ambitious a policy is. This chapter employs the Index of Policy Activity (IPA) used throughout this volume to do so, comparing the policy intensity of policy instruments in three EU environmental policy subsectors (environment-industry, air quality, and climate/energy policy). The IPA provides a shared system of terminology and weighting of the importance of different factors. With this type of comparability, it is possible to examine whether climate policy and other environmental policies have evolved differently at the EU level after the crisis. 


\section{Methods and case study selection}

\section{Methods: Adapting the Index of Policy Activity}

Policy intensity, used alongside policy density - the number of policy instruments - allows researchers to gauge the ambition of a policy. In one approach, research by Steinebach and Knill (2016) and by Gravey and Jordan (2016) focused on policy scope (how encompassing a policy is) and policy settings (how strict a policy is). In another, Gravey (2016) further considered formal intensity, that is issues pertaining to enforcement, implementation, and "the factors affecting the probability that substantial requirements are effectively achieved" (Bauer and Knill, 2012: 35). Hence, how best to measure intensity is currently under discussion. As a result, a variety of intensity indicators are used in the literature. Steinebach and Knill (2016) combine density and intensity in a single indicator, while Gravey and Jordan (2016) use two density and four intensity indicators, to which Gravey (2016) adds a fifth indicator (formal intensity).

This chapter builds on the Index of Policy Activity (IPA) approach to policy intensity developed by Schaffrin, Sewerin, and Seubert $(2015,2014)$ because it allows for comparison between different subsectors as well as between new and pre-existing policies. The IPA is one way of opening the black box of policy intensity and provides a number of indicators that can be measured and compared over time. The IPA focuses on policy intensity and offers six indicators - objectives, scope, integration, budget, implementation and monitoring (see Chapter 2 for details) - encompassing Bauer and Knill's (2012) categories of substantive and formal intensity.

The IPA has two further unique features. First, in contrast to coding that focuses only on regulatory standards, the IPA has been used to analyze six different policy types, from soft measures such as information programs, to market-based and regulatory instruments (Schaffrin et al., 2015: 285). This makes it possible to gauge not only changes in ambition but also in the type of instruments used between different countries, sectors, or over time. Second, contrary to research that analyzes relative changes between two generations of the same legislative instrument (as in Gravey and Jordan, 2016), analysis 
using the IPA produces an absolute grade. ${ }^{1}$ This makes it possible to use the same coding scheme for policy proposals, new legislation, and revisions to existing policies.

In-depth coding of policy change requires attention to detail - with the coding scheme often developed to fit the policy sector studied. The IPA originally focused on climate policy instruments in the energy production sector, which shaped the coding framework (Schaffrin, Sewerin, and Seubert, 2015: 264265). To investigate changes to EU environmental policy defined more broadly, several challenges were encountered, and the coding scheme was revised in response. The first challenge concerned the objectives indicator. Climate and energy policies can often be compared to percentage targets for emission reductions or renewable energy production. In contrast, many other environmental policies do not have fixed internationally-agreed numerical objectives against which they can be judged (for example EU sustainable consumption and production policies have only non-binding, non-numerical objectives, see European Environment Agency, 2013). In addition, policies such as those focusing on air or water pollution often have multiple regulatory standards, each with distinct objectives. These differences required an expanded number of approaches to calculating the objectives indicator (especially in the environment-industry and air quality subsectors). The second challenge concerned the scope indicator. The IPA's coding criteria were originally designed to analyze climate-related energy policy. Therefore, the criteria were reworded to be more encompassing, taking into account a larger number of environmental issues and businesses/industry sectors.

The third challenge concerned the budget indicator, which raised two issues. First, the lack of a budget in many regulatory policies makes these instruments de facto less intense if they are scored using this indicator when using the IPA (because they are given a score of 0 out of 1 on one of the six IPA dimensions). However, equating a budget with higher policy intensity is potentially problematic when dealing with regulation and comparing it to policy types with large budgets such as subsidy programs. Strict regulatory standards can have a profound impact on regulated sectors but have only a small budget and no explicit financial imposition. Second, subsidiarity and multi-level governance means that an EU

\footnotetext{
${ }^{1}$ Burns and Tobin (2016) also provide absolute grades of policy ambition.
} 
policy's implementation budget might be coordinated by the individual EU Member States. This means those budgets fall outside the EU scope - and therefore an EU-focused use of the IPA. Schaffrin, Sewerin, and Seubert dealt with this issue by not including the budget indicator when scoring policy instruments such as framework policies that are unlikely to command large budgets (2015: 270). For consistency, all policies analyzed in this chapter are scored on the budget indicator. However, the lack of a budget in most EU policies should be noted when comparing policy intensity across levels of governance (for example, when comparing EU policy with national policy in other chapters in this volume).

\section{Case study selection}

After the economic crisis, there were concerns both that environmental policy in general had suffered (Čavoški, 2015), and that traditional sectors of environmental policy had been more affected than newer sectors such as climate policy (Gravey, 2016). These concerns were reinforced by changes in the organization of the European Commission's directorate-generals for environmental policy. The first change occurred in 2010, when climate change policy and other environmental policy areas were separated following the creation of DG Climate Action. The second change occurred in 2014, when environmental portfolios were merged with non-environmental portfolios under the Commissioner for Environment, Maritime Affairs, and Fisheries (in the case of DG Environment) and the Commissioner for Climate Action and Energy (in the case of DG Climate Action). Interviews drawn from previous research suggest that these shifts had an important effect on EU policy (Gravey, 2016). An interviewee at an environmental NGO stated:

There has been this very successful game of dividing climate from the environment. Which by the way has done a huge amount of damage at many different levels. . . Certainly we've seen that the split between DG Environment and DG CLIMA has been disastrous. (Environmental NGO interviewee, November 2014)

This pessimistic view was confirmed by a European Commission official: 
In the last Barroso II mandate, [DG Environment] had a hard time, they were pushed back a lot. And the regulatory simplification or the lightening of the burden fell quite heavily on them compared to [DG] Climate Action for instance. They were seen as a little bit too burdensome really (European Commission interviewee, June 2015)

However, despite qualitative evidence of this divide, little is known about how environmental policies have evolved at EU level over the last twenty years, and after the start of the economic crisis in particular. Attempts to code changes to EU environmental policies have tended to focus on a small number of policies, offering limited possibilities for comparison. In particular, there has been no comparison of the policy intensity of EU environmental policy generally and EU climate policy since the two were separated in the European Commission.

In order to contribute to filling this gap, this chapter focuses on the three shared research questions addressed throughout this volume (order of change, direction of change, and strategy) supplemented by a fourth question: has EU climate policy been affected differently than other EU environmental policy? To address these four questions, this chapter compares changes to three sub-sectors of EU environmental policy: environment-industry policy, air quality policy, and climate and energy policy. The first subsector, environment-industry policy, is both at the heart of the move to a Green Economy in Europe (European Environment Agency, 2013) and often criticized for imposing high regulatory burdens on companies. As a result, these policies were openly targeted by EU industry ministers as negatively impacting competitiveness (Wall Street Journal, 2012). There are eleven environmentindustry policy instruments that are listed under "Industry" on the DG environment website ${ }^{2}$, four that are based on EU regulations or directives and seven soft instruments set out in non-legislative texts.

The second subsector, air quality policy, is an older area of EU environmental policy which first started in the 1980s. This legislation sets ambient air standards and covers pollution from maritime and road transport as well as specific industrial pollution sources. The EU's air quality policy framework was

\footnotetext{
${ }^{2}$ http://ec.europa.eu/environment/industry/
} 
reviewed in 2012-2013 ${ }^{3}$, and has come under heavy criticism in the wake of the Volkswagen emission scandal. This criticism means that both the environment-industry and air quality subsectors offer an interesting case study of the green credentials of the EU's response to the financial and economic crisis (Warleigh-Lack, 2010).

The third subsector, climate and energy policy (specifically climate mitigation to reduce greenhouse gas emissions) is more recent than its counterparts but has grown rapidly in recent years. The policy intensity analysis in this chapter focuses on six climate and energy policy instruments: the EU Emissions Trading System, EU effort sharing of greenhouse gas reductions, energy efficiency, and three instruments related to the EU's targets for renewable energy production. The analysis focused on renewable energy and energy efficiency instruments adopted after 2000, and so did not include earlier legislation such as the SAVE and ALTENER programs adopted in the 1990s. Together, the EU ETS and effort sharing cover $100 \%$ of the EU's domestic GHG emissions excluding land use, land use change, and forestry (the EU ETS covers approximately $45 \%$ of these emissions, with effort sharing legislation covering the remainder). Together with the renewables and energy efficiency instruments, they implement the EU's headline climate and energy goals.

\section{Results}

This section compares the evolution of the three EU environmental policy subsectors on three dimensions. First it analyzes the "legal types" used in each subsector (legislative and non-legislative instruments). Second, it looks at policy instrument types and classifies policies in each subsector into five categories: soft measures, market-based instruments, framework policies, public investment, and regulatory instruments (Schaffrin et al., 2015: 282). Third, it analyzes changes to policy intensity using the IPA.

\footnotetext{
${ }^{3} \mathrm{http} / / /$ ec.europa.eu/environment/air/index_en.htm
} 


\section{Legal types}

This section presents the legal types used in each EU environmental policy subsector. An analysis of legal types distinguishes between legislative (European directives and regulations) and non-legislative instruments (such as European Commission Communications), and studies whether their use differs across subsectors.

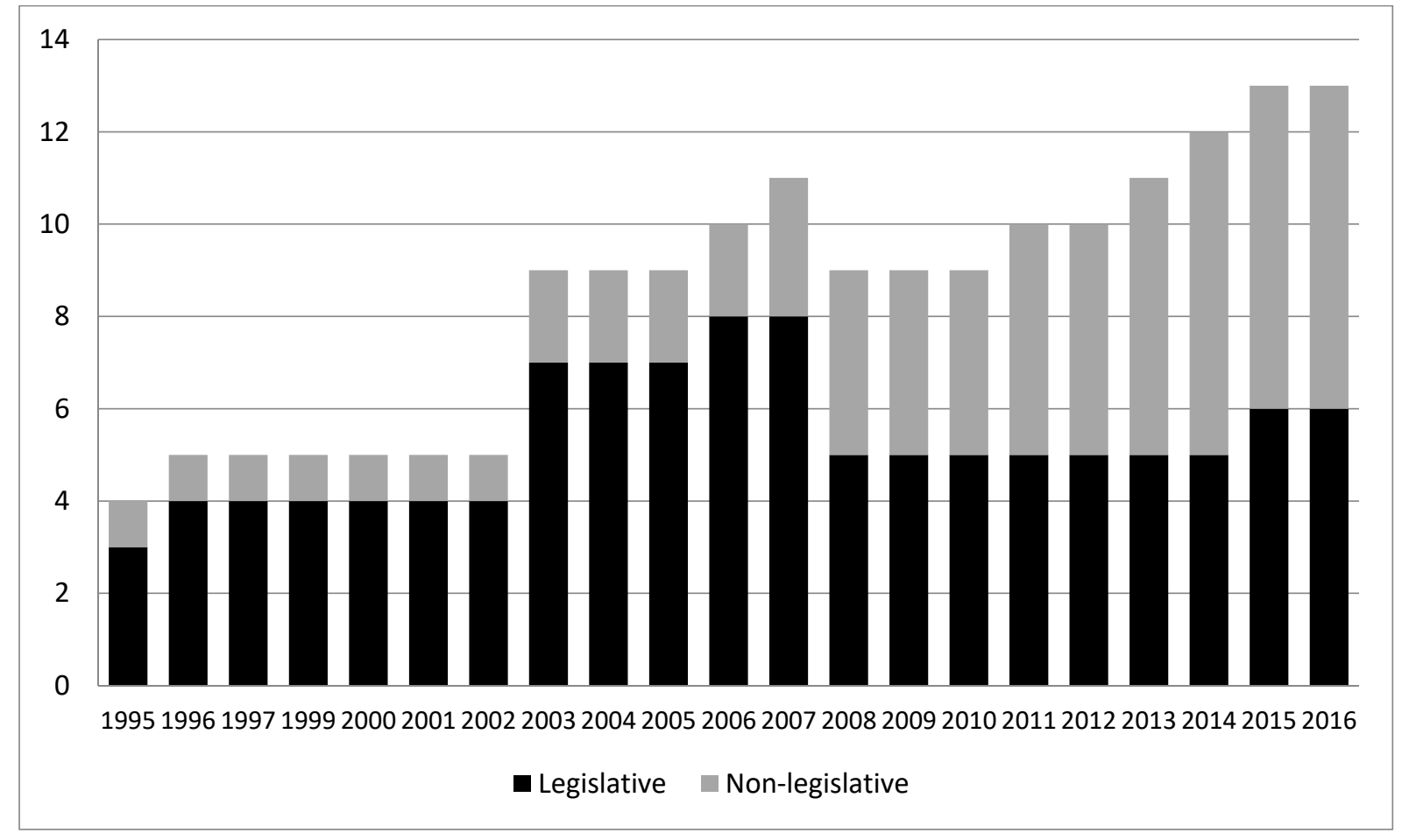

Figure 1 Legal types in the EU environment-industry policy subsector (1995-2016). Note: Non-legislative policy is not included in the policy intensity analysis below.

EU environment-industry policy has long contained a mix of different legal types (Figure 1), including the use of non-legislative instruments such as the European Awards for the Environment first launched in 1987. Legislation on industrial accidents and industrial emissions was adopted in the 1980s and 1990s. Over time, the balance of the policy mix has increasingly shifted towards the use of nonlegislative instruments, such as the Eco-innovation Action Plan (launched in 2011 to facilitate the uptake of environmentally-friendly innovations), and initiatives to reduce the environmental impacts of products (Integrated Products Policy). A different picture emerges when considering air quality policy (Figure 2). There, legislative instruments have remained dominant since the 1970s, with their revisions planned under non-legislative strategies, including Clean Air for Europe (adopted in 2001) and the Clean Air Programme (adopted in 2013). 


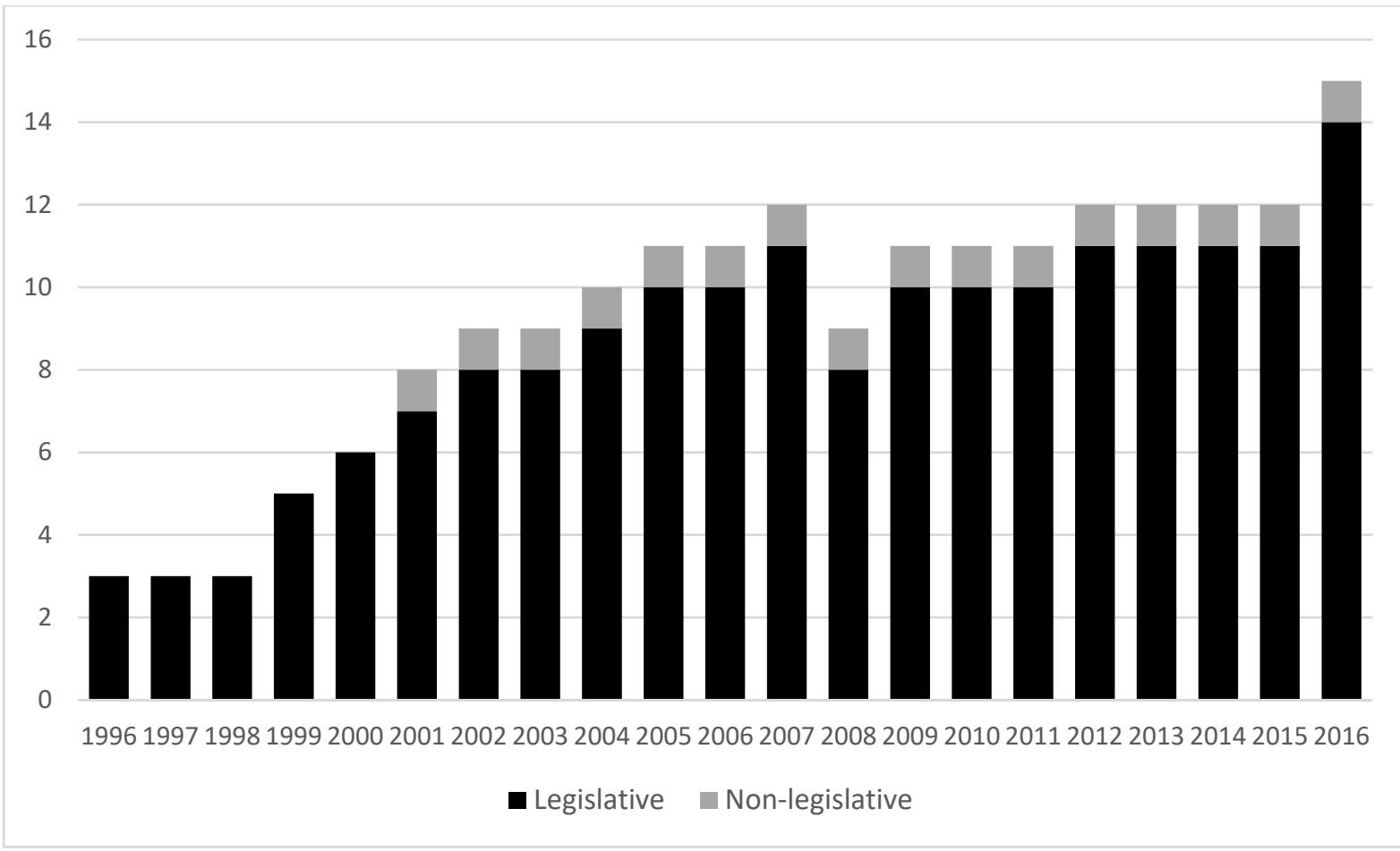

Figure 2 Legal types in the EU air quality policy subsector (1996-2016). Note: Non-legislative policy is not included in the policy intensity analysis below.

EU climate and energy policy has grown to include nineteen distinct pieces of legislation in 2016

(Figure 3). This refers to climate mitigation policy and not, for instance, adaptation policy (cf. Nachmany et al., 2015). This legislation has been adopted in the context of non-legislative European Council conclusions which set the strategic direction for policy, such as the 2030 Climate and Energy Framework adopted in October 2014 (European Council, 2014). 


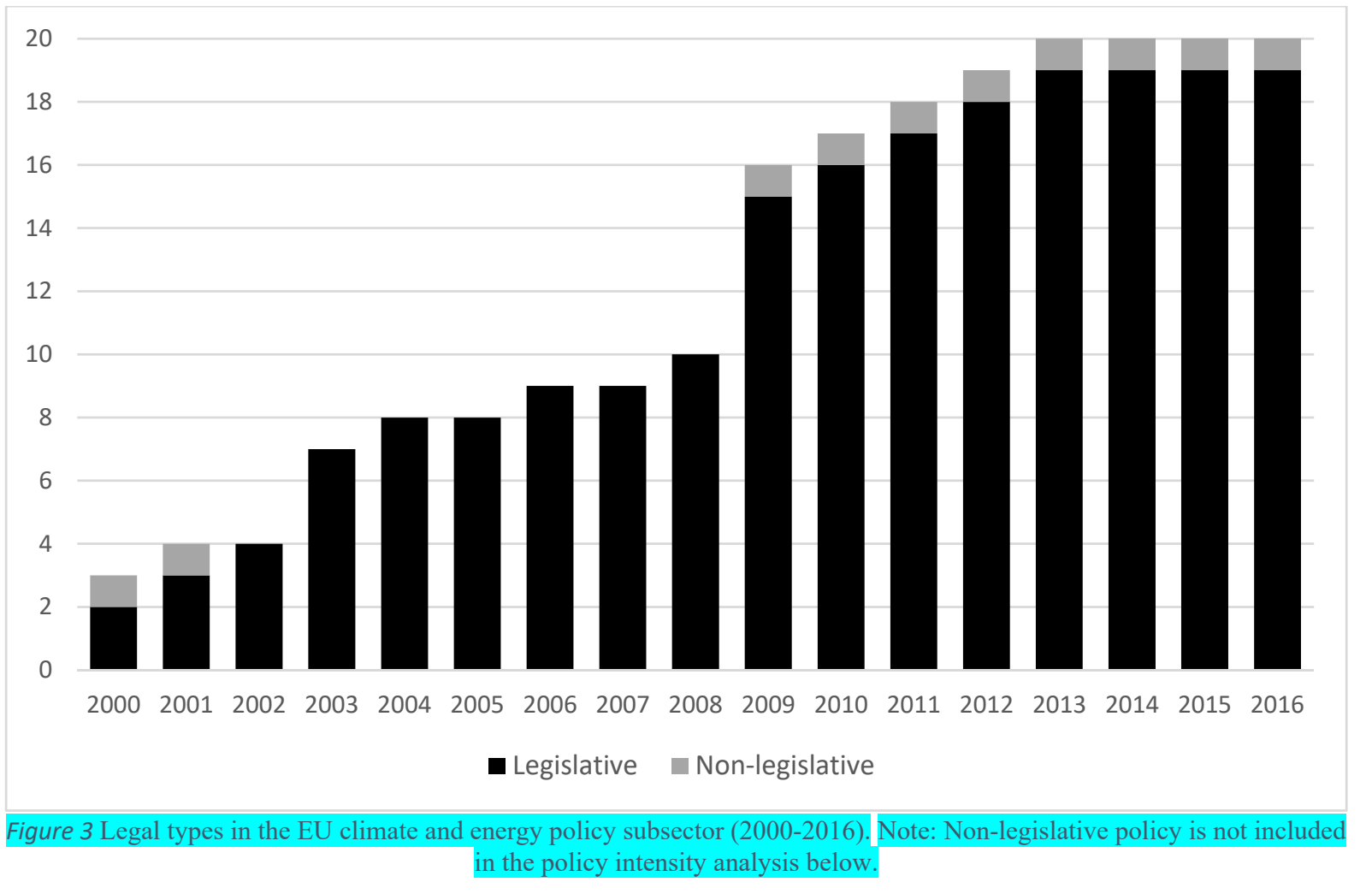

\section{Policy instrument types}

The three EU environmental policy subsectors each make use of a distinct mix of policy instrument types (Table 1). Environment-industry policies are characterized by the frequent use of what Schaffrin et al. (2015: 26) call 'soft measures', that is education, information, and voluntary agreements. Only two of the pieces of environment-industry legislation contain traditional regulatory instruments. Air quality policy relies much more strongly on the use of regulatory instruments, although it still uses framework instruments (for example, to set the share of effort of different Member States under the National Emissions Ceiling Directive). It also includes soft measures that principally target public information about air quality. Climate and energy was the only subsector studied that included a marketbased instrument (the EU ETS), and otherwise the instruments studied with the IPA served as both regulatory instruments and framework policies. This analysis further highlights the fact that instrument types and legal types do not necessarily overlap. For example, the European Ecolabel is considered an example of a 'soft measure', but contrary to other 'soft measures' or voluntary measures such as the Single Market for Green Products Initiative, it was set out in EU legislation (it is therefore an example of soft policy that was adopted as hard law). 


\begin{tabular}{|c|c|c|c|c|c|}
\hline & $\begin{array}{c}\text { Public } \\
\text { Investment }\end{array}$ & $\begin{array}{c}\text { Soft } \\
\text { Measure }\end{array}$ & $\begin{array}{c}\text { Framework } \\
\text { Policy }\end{array}$ & $\begin{array}{l}\text { Regulatory } \\
\text { Instrument }\end{array}$ & $\begin{array}{l}\text { Market- } \\
\text { based } \\
\text { Instrument }\end{array}$ \\
\hline Environment-Industry & - & 4 & - & 2 & - \\
\hline Air Quality & - & 2 & 2 & 4 & - \\
\hline Climate and Energy & - & - & 6 & 6 & 1 \\
\hline Overall & 0 & 6 & 8 & 12 & 1 \\
\hline
\end{tabular}

\section{Index of Policy Activity}

This section presents the analysis of policy intensity for the three policy subsectors, as well as an overall comparison of the evolution of policy intensity over time.

\section{Environment-Industry Policy}

The four environment-industry policy instruments analyzed using the IPA were the Ecolabel scheme, the Eco-Management and Audit Scheme, the Industrial Accidents directives, and the Industrial Emissions directives.

\section{Ecolabel scheme}

The Ecolabel scheme is a voluntary instrument for European businesses to publicize their green credentials to their customers. It was adopted in 1992 and has been revised three times in 2000, 2010, and 2013. Using the IPA to analyze the Ecolabel scheme raised a number of challenges. First, there is no clear, externally-agreed baseline against which to gauge the scheme's objectives. Prior to 2010, the Ecolabel policy did have a clearly stated objective to "promote products which have the potential to reduce negative environmental impacts, as compared with the other products in the same product group" and to provide "guidance and accurate, non-deceptive and scientifically based information to consumers" (European Parliament and Council of the European Union, 2000). However, this objective was removed as part of the 2010 revision - causing the objectives indicator to decrease. The scope indicator increased as the scheme was opened to a growing number of businesses as well as covering a varied number of environmental issues. Implementation increased in intensity with the creation of a 
EU-wide Ecolabel Board, the introduction of infringement procedures, and the addition of penalties. Overall, apart from objectives, Ecolabel policy intensity rose both before and after 2008.

Eco-Management and Audit Scheme (EMAS)

EMAS is a voluntary scheme that allows businesses to demonstrate improvements in their environmental performance and management. It was adopted in 1993, was revised twice in 2001 and 2009, and is currently undergoing a REFIT evaluation. The objectives and budget indicators were coded following the same approach as for the Ecolabel scheme. Post-adoption reforms increased the policy's integration, scope (to cover a larger number of organizations and environmental issues), and implementation (with more effective provisions for non-compliance). Overall, policy intensity increased or remained the same (e.g., budget, monitoring) in all IPA categories.

\section{Industrial Accidents Directives (SEVESO)}

The Industrial Accidents Directives set out rules for companies engaged in industrial activities regarding accident planning and the provision of information to government authorities and the public. They were first adopted in 1982 after the 1976 Seveso industrial accident exposed the failings of Community rules on hazardous waste disposal and accident prevention. The Directives have been revised three times in 1996, 2003, and 2012. Integration (with other land use policies) and implementation (tougher penalties) are the two dimensions which increased the most. Overall, policy intensity increased or remained unchanged in all IPA categories.

\section{Industrial Emissions Directives}

The Industrial Emissions Directives set out rules for pollution prevention and control - in particular the concept of "best available technology" - and incentivize European industries to improve their actions against pollution. First adopted in 1996, the Directives saw three rounds of revisions in 2008, 2010, and 2015. These revisions increased policy scope by covering a growing number of industries and strengthened policy implementation by introducing penalties. Overall, policy intensity increased or remained unchanged in all IPA categories. 
In summary, the average policy intensity of the four EU environment-industry policies rose by $50 \%$ between 1995 and 2016 (Figure 4). This increase was largely due to parallel reforms of Ecolabel and EMAS in 2001 and another reform of EMAS in 2009. With the exception of the Ecolabel scheme's objectives, all IPA indicators increased or remained the same in this policy subsector when comparing 1995 and 2016.

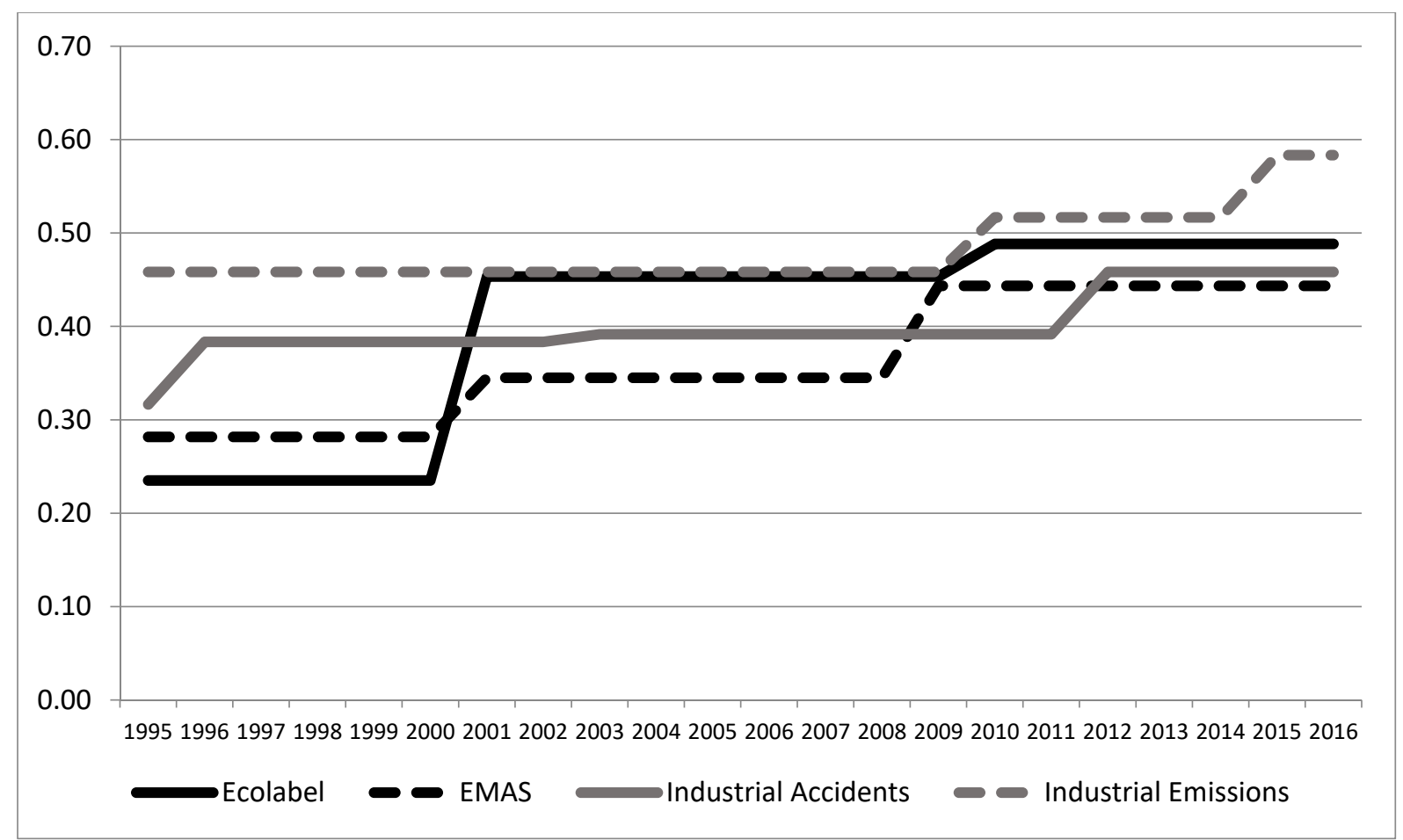

Figure 4 Policy intensity of EU environment-industry policy (1995-2016) as measured by the Index of Policy Activity.

\section{Air Quality Policy}

The four air quality policies analyzed using the IPA were related to ambient air quality, the National Emissions Ceiling Directive, air pollutants from road transport, and air pollutants from maritime transport.

\section{Ambient Air Quality}

EU legislation on ambient air quality began with a narrow focus on key pollutants in the 1980s (lead and sulfur), before moving toward a framework approach with the adoption of the 1996 directive on ambient air quality assessment and management. This directive spawned four "daughter" directives 
focusing on specific pollutants, and was replaced by a new framework directive in 2008. Ambient air policy has seen a fall in IPA scores from their peak, caused by a sharp decrease in the policy intensity of its objectives, from a score of 1 in 2002 to 0.6 in 2008. This decrease can be explained by the fact that the ambient air objectives were analyzed using World Health Organization (WHO) guidelines as a baseline. The WHO guidelines have become markedly more stringent due to new research on the health impacts of air pollution. Despite becoming more stringent itself, EU legislation failed to keep pace with these changes. This was in part because EU Member States failed to comply with the existing, lessstringent standards, leading the European Commission to worry that increasing stringency would be "counter-productive" (European Commission, 2013: 3). Aside from the objectives, all other indicators remained stable or, in the case of implementation, increased slightly.

\section{National Emissions Ceiling Directive}

The National Emissions Ceiling Directive limits EU Member State emissions of nitrogen oxides, sulphur dioxide, ammonia, fine particulate matter, and non-methane volatile organic compounds. The Directive was adopted in 2001 and revised in 2006 and 2016. The Directive's overall policy intensity has increased as a result of its integration in the EU clean air package and a slight increase in the environmental issues included in its scope, partly offset by a reduction in the implementation indicator due to increased flexibility in meeting emissions ceilings. The objectives, monitoring, and budget indicators did not change during the time period studied.

\section{Air pollutants from road transport}

EU rules on air pollutants from road transport aim to limit emissions of pollutants such as nitrogen oxides, carbon monoxide, and particulate matter. First adopted in 2007, this legislation was revised in 2008, 2009, 2011, and 2016. These revisions included new rules adopted in 2016 in the wake of the Volkswagen scandal, which introduced tests for "real driving emissions" (European Commission, 2016). However, the original Volkswagen scandal was followed by other developments (such as the ongoing Commission investigation into cartels in German car manufacturing) that raised the possibility that German manufacturers jointly agreed to build air-pollution devices which they knew would not 
effectively trap NOx. ${ }^{4}$ These repeated scandals placed added pressure on the EU and how it is lobbied by, and regulates, the European car industry. In this context, since 2007 both scope and objectives have increased slightly, with more pollutants tested and stricter tests introduced. The integration, budget, implementation, and monitoring indicators have remained stable throughout this period.

\section{Air pollutants from maritime transport}

EU legislation on air pollutants from maritime transport limits the sulphur content of fuels and addresses other pollutants such as nitrous oxides. The EU legislated first on the sulfur content of different fuel types in 1999, before focusing further attention on marine fuels in 2005 and 2012 to fulfill its international commitments under the MARPOL convention. These regulations score highly in terms of objectives as they meet MARPOL targets, and the legislation also increased in scope to cover heavy fuels, marine gas oils, and diesel fuels.

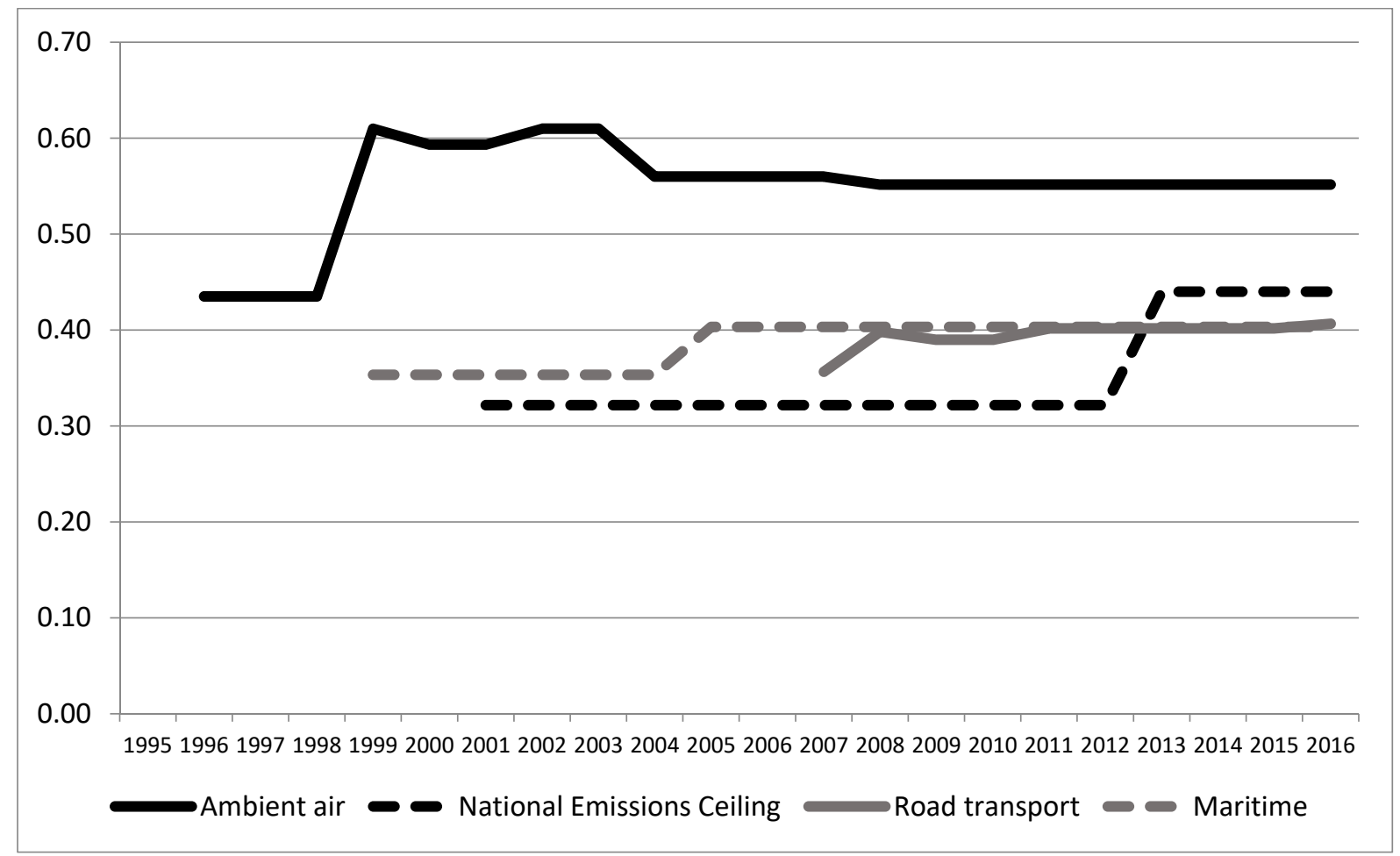

Figure 5 Policy intensity of EU air quality policy (1995-2016) as measured by the Index of Policy Activity.

\footnotetext{
${ }^{4}$ https://www.politico.eu/article/germany-cars-cartel-dieselgate-brussels-vows-to-piece-together-automotiveemissions-puzzle/
} 
In summary, every air quality policy saw increases in policy intensity post-adoption, and none saw significant decreases after the economic crisis (Figure 5). However, the average policy intensity of the air quality subsector in 2016 (0.45) was nearly identical to its intensity in 1996 (0.44). A significant post-adoption increase in intensity for ambient air legislation was offset by the addition of other, less stringent policies (maritime transport, National Emissions Ceiling, and road transport).

\section{Climate and Energy Policy}

This section focuses on the EU Emissions Trading System (EU ETS), the EU's effort sharing agreements on greenhouse gas reductions, and post-2000 EU legislation on renewable energy and energy efficiency.

\section{The EU Emissions Trading System (EU ETS)}

The EU ETS is a "cap-and-trade" system that sets a limit on greenhouse gas emissions from electricity generation, energy-intensive industries, and aviation. Installations covered by the EU ETS are required to surrender an "emission allowance" for every ton of greenhouse gases they emit each year. These allowances may be bought and sold by regulated installations and other organizations. Adopted in 2003 and in operation since 2005, the EU ETS has undergone five major revisions in 2008, 2009, 2013, 2015, and 2018. The objectives indicator for the EU ETS was calculated in two parts. Half of the indicator was based on the ETS's emission reduction target in a given year, calculated in comparison with an $80 \%$ reduction in emissions by 2050 . The other half of the indicator was based on the price of ETS emission allowances as a percentage of the maximum price in the ETS's history (€34). The scope indicator was calculated by dividing the annual number of emission allowances allocated under the EU ETS by the total greenhouse gas emissions in the EU in that year. Finally, for simplicity the budget indicator was based on the percentage of emission allowances that were sold at auction (which provided revenue for Member State governments as well as EU-level funding for low carbon investment).

Implementation and monitoring stayed stable throughout the period studied. The integration indicator increased from 0 to 1 in 2009 after the ETS was integrated into the 2020 Climate and Energy Package. The EU ETS's scope has varied depending both on its own rules and the level of EU greenhouse gas 
emissions, but the IPA scope indicator fluctuated within a narrow range between 0.4 and 0.5 , while the objectives indicator largely stayed below 0.3 due to the low prices of emission allowances and lowstringency reduction targets. Finally, the percentage of auctioning in the budget indicator was very low until the implementation of the 2009 directive, when it jumped to above $40 \%$. The EU ETS's overall IPA score was stable or increased between 2005 and 2016, aside from two small decreases in 2007 and 2012 driven by the objectives indicator.

\section{EU Effort Sharing}

The EU's effort sharing agreements divide up targets for greenhouse gas reductions so that wealthier countries have stricter requirements. Effort sharing was originally adopted in 1997, implemented in 2002, and revised in 2009 and 2017. The ETS and effort sharing have the same scores for monitoring, implementation, and integration. The objectives indicator was calculated as a percentage of an $80 \%$ emission reduction. This indicator stayed in a narrow range near 0.10 between 2005 and 2015, and then jumped to 0.38 with the publication of the Commission's proposal for effort sharing after 2020. Similar to the environment-industry policies analysed previously, effort sharing did not have a significant EUlevel budget. The scope was calculated using the percentage of EU greenhouse gases addressed by effort sharing agreements. From 2005 to 2012 effort sharing addressed all of the EU's emissions. Starting with the 2009 Effort Sharing Decision, this scope was changed to those greenhouse gas emissions that were not covered under the EU ETS. As a result, the EU ETS and EU effort sharing changed from being overlapping policies to being parallel policies covering distinct sectors of the economy. For effort sharing, this meant a significant reduction in scope after 2012. In sum, the overall intensity measure for effort sharing increased in 2009 and again in 2016.

\section{Renewable Energy}

The EU set renewable energy targets for electricity generation in 2001 and biofuels in 2003 . These separate pieces of legislation were replaced by the 2009 Renewable Energy Directive, and in 2016 the European Commission released a proposed revision for after 2020. Policy intensity almost doubled in 2009 due to a wider scope, more stringent objectives, and integration with other climate and energy 
policies. Although the objective was increased again in the 2016 proposal, the renewable target for 2030 was no longer binding at Member State level. This led to a small reduction in overall policy intensity in 2016.

\section{Energy Efficiency}

The EU adopted legislation on end-use energy efficiency in 2006, which was replaced by the Energy Efficiency Directive agreed to in 2012. From 2006 to 2011 policy intensity was much lower than other climate and energy policies at 0.22 . Similar to renewable energy policy, a wider scope, more stringent objectives, and integration with other polices led to a doubling of the intensity score in 2012.

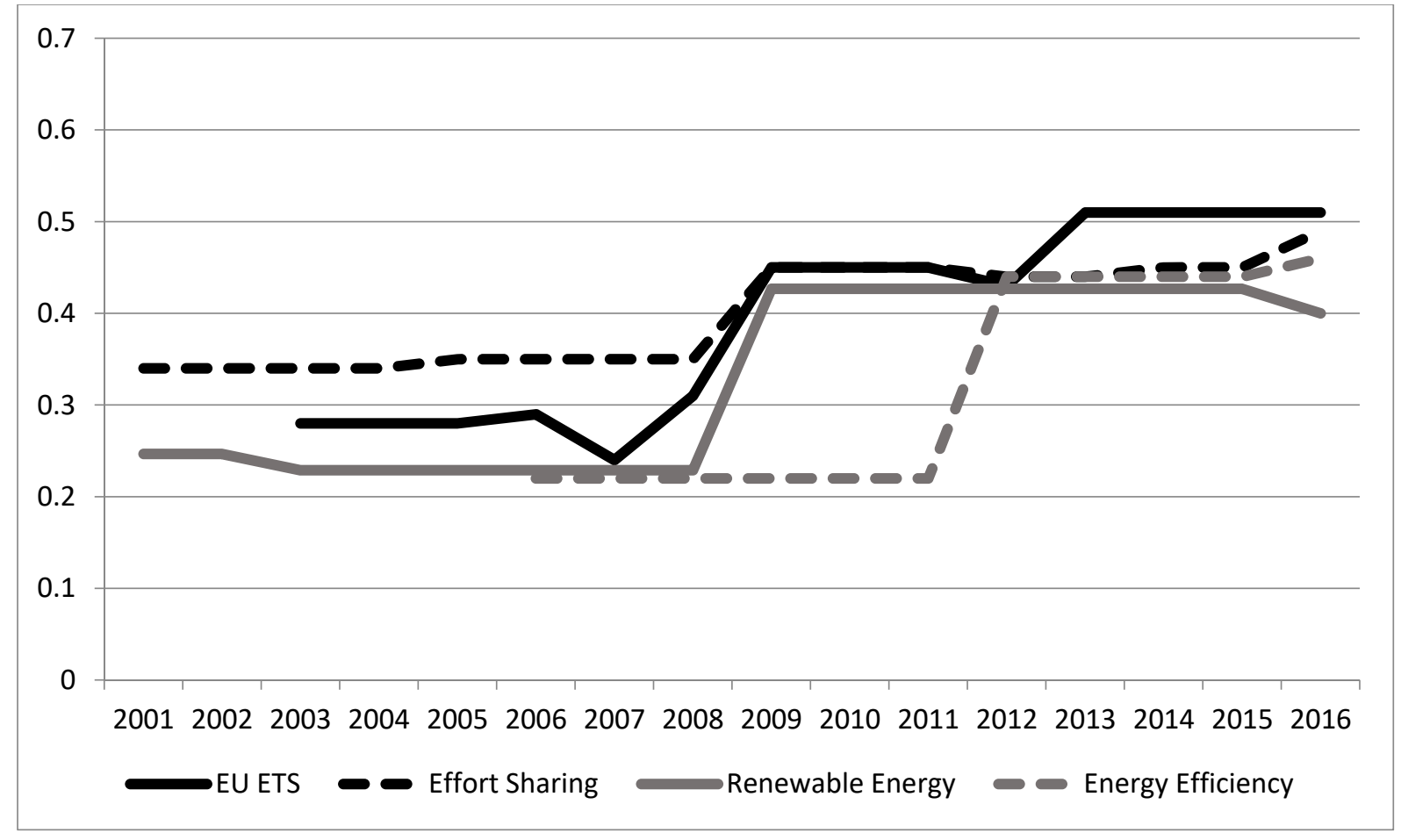

Figure 6 Policy intensity of selected EU climate and energy policy (2001-2016) as measured by the Index of Policy Activity.

In summary, after falling slightly between 2001 and 2008, the IPA score for climate and energy policy increased substantially up to 2016 (see Figure 7 below). This post-crisis increase was driven in large part by the integration of the policy instruments in the 2020 Climate and Energy Package, and increased targets related to the objectives indicator. All four policies increased in intensity, with relatively higher increases for the EU ETS, renewable energy, and energy efficiency. 


\section{Overall Comparisons}

The average policy intensity of the three subsectors - environment-industry, air quality, and climate/energy - converged over the period from 2001 to 2016 (Figure 7). Both air quality and environment-industry remained remarkably stable prior to the crisis, with a slight increase for environment-industry since 2008. Climate and energy policy initially lagged behind the other subsectors, but rose substantially between 2008 and 2009, and reached parity after the economic crisis.

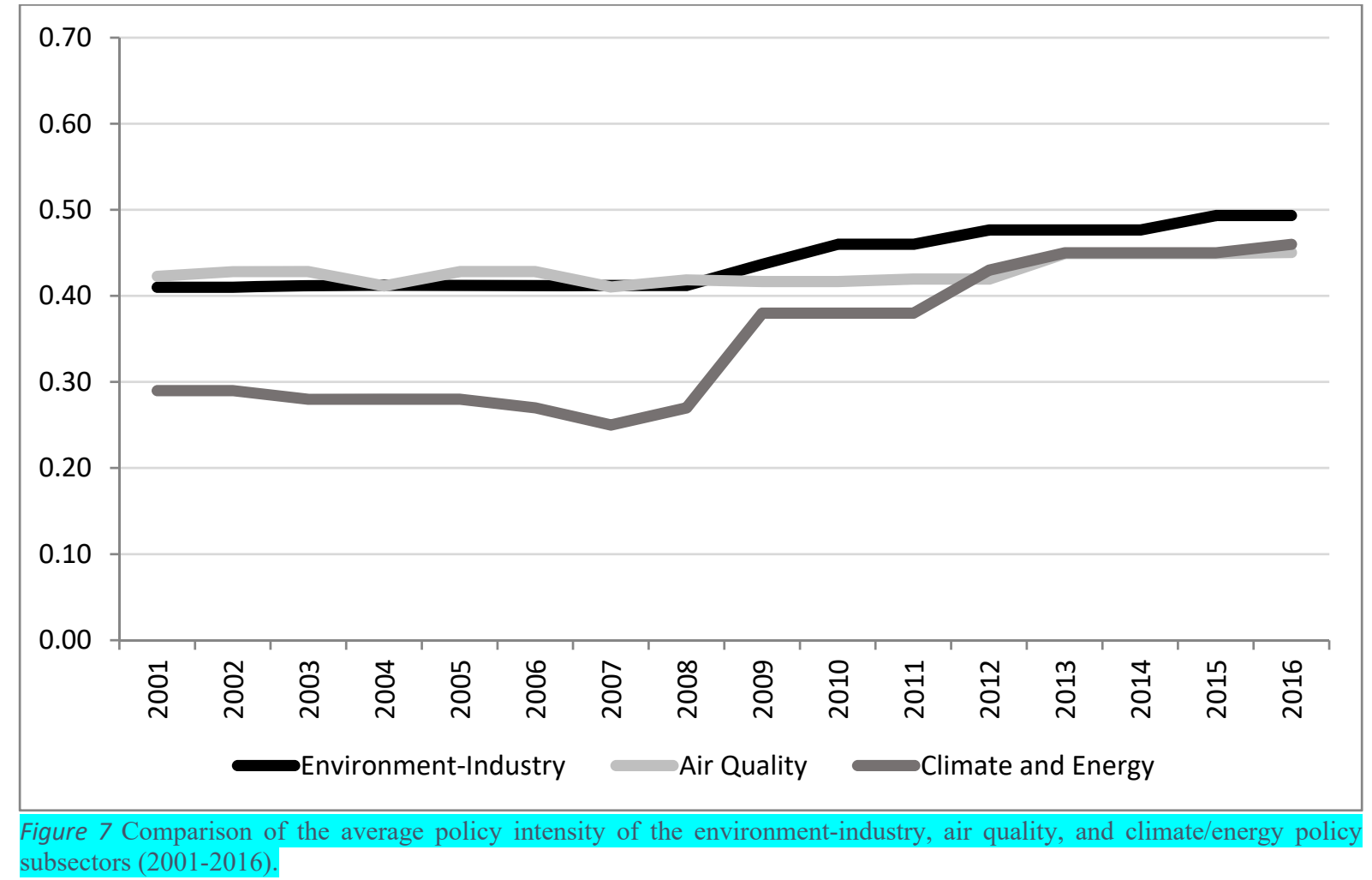

Figure 8 illustrates the comparatively significant increase in climate and energy policy intensity since the crisis in comparison to the other subsectors. Both environment-industry and air quality policy also show increases in intensity, though of a much more modest scope. 


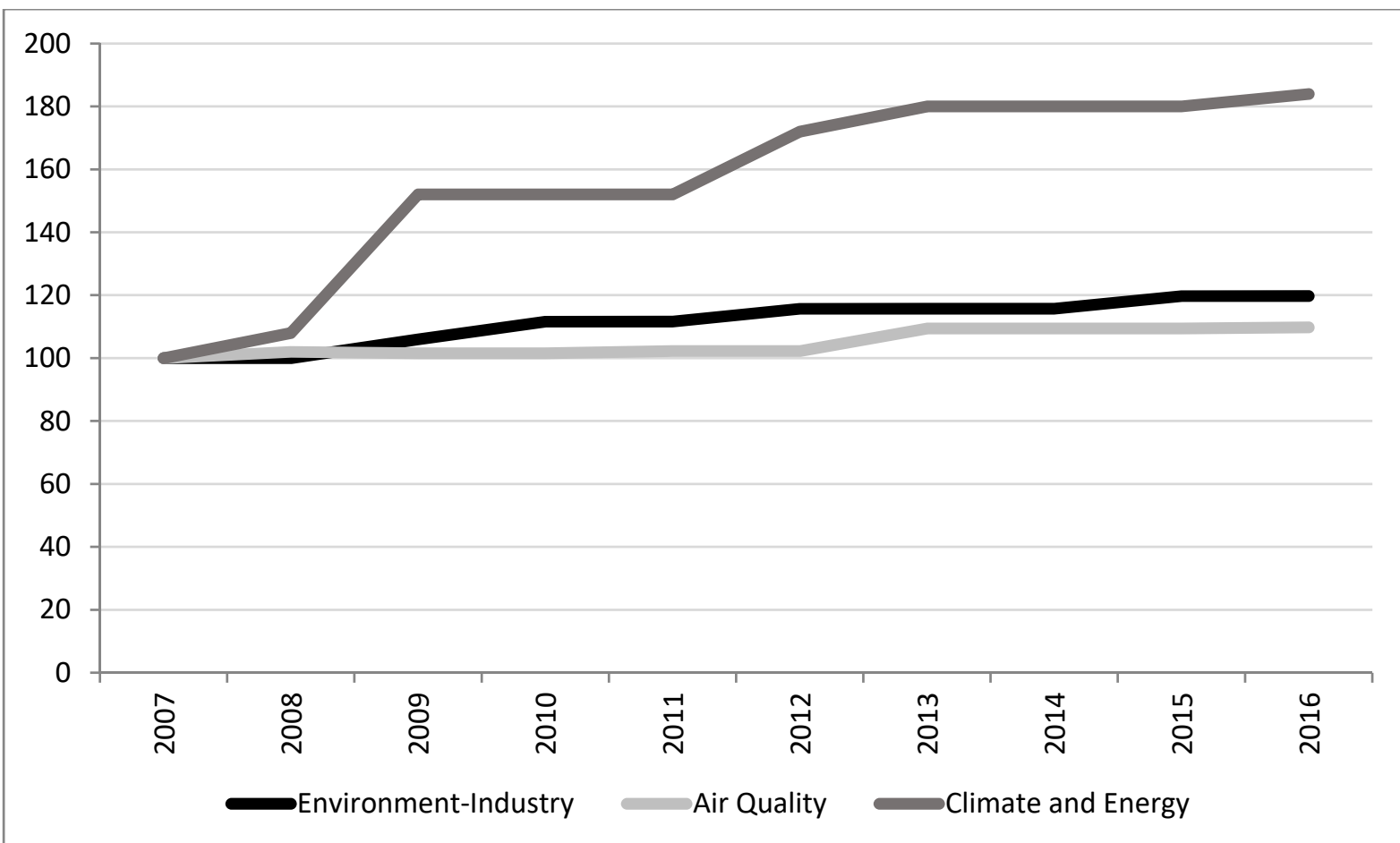

Figure 8 Comparison of the change in average policy intensity of the environment-industry, air quality, and climate/energy policy subsectors, indexed to the policy intensity in 2007.

\section{Discussion}

Despite widespread concern that EU environmental policies have been weakened by the economic crisis, our analysis of selected policies in three subsectors using the IPA found that policy intensity increased both before and after 2008. This appears to confirm Slominksi's (2016: 353) contention that environmental policies are "not only widely accepted by EU citizens but also firmly embedded into inter- and supranational policy regimes and will thus continue to play an important role in EU politics" after the crisis. While the three subsectors appear to be moving in the same direction, the climate and energy subsector increased in intensity much more than environment-industry or air quality, though from a lower pre-crisis level. How do these results compare to the existing literature? Both this chapter and Gravey and Jordan (2016) found an overall trend toward increased policy intensity, with dismantling or reduced ambition only true for a small number of cases, and a small number of dimensions within these cases. Overall, the trend in both air quality and environment-industry is toward greater intensity and policy expansion, which echoes existing research in these sectors and others (Gravey and Jordan, 2016; Steinebach and Knill, 2016). 
Contrary to Gravey and Jordan (2016) our coding of changes to environment-industry policies did not detect evidence of dismantling or reduced intensity (apart from the Ecolabel scheme's objectives). Gravey and Jordan (2016) found a small number of dismantling events - such as reduced instrument scope in the Ecolabel scheme - which could not be captured by the IPA index. Considering changes to EU environmental policy up to 2005, Hey argued that "the revision of the Seveso, the Ecolabel and EMAS-directives generally [led] to more ambitious standards and a more comprehensive system of protection" (2005: 26). The current analysis suggests that this trend continued after 2005, irrespective of the 2008 financial crisis. Conversely, our results show stable policy intensity in the air quality subsector between 1995 and 2016, driven mainly by changes to ambient air quality legislation not apparent in Gravey and Jordan (2016) or Steinebach and Knill (2016). By linking EU policy objectives with internationally-agreed targets, the IPA approach suggested a sharp drop in EU ambition in tackling ambient air pollution driven by the growing gap between EU and WHO standards. On the other hand, Gravey and Jordan again identify minor instances of dismantling in the air quality subsector - such as greater margins of tolerance for lead pollution under the ambient air directive - that are not apparent when using the IPA.

Regarding climate and energy policy, the findings for the EU ETS stand in contrast to Burns and Tobin (2016), who found reduced EU ETS ambition post-crisis (although they too found an increase related to effort sharing). This may be because Burns and Tobin analyze the ambition of individual revisions in relation to existing policy, and not the ambition of the policy instrument as a whole over time. The increases in policy intensity for effort sharing, renewable energy, and energy efficiency are in line with literature on the topic (Boasson and Wettestad, 2013; Bürgin, 2015). An important caveat related to climate and energy policy is that the revisions which increased policy intensity in 2009 were the result of political negotiations that largely pre-dated the onset of the global financial crisis in September and which were agreed to only two months later in December 2008 (European Council, 2008).

Taking a step back, these different coding efforts appear to point in a similar direction: showing that, despite what may be strong changes in discourses and policy framing, the EU environmental policy subsectors analyzed here appear to have withstood the economic crisis fairly well. This appears to be 
confirmed by the publication of the REFIT evaluation of the EU's flagship Birds Directive and Habitats Directive, which found both of them fit for purpose, strongly diminishing the case for their reform and potential dismantling. ${ }^{5}$ The overall increase in policy intensity found here needs to be further tested. First, it would be useful to test the limits of the IPA coding scheme and identify to what extent the increase in policy intensity is an artifact of the method used. As Green-Pedersen argued, "there is no such thing as retrenchment per se" (2004: 7), only different definitions of a dependent variable. The same holds true for all coding of policy change. This chapter analyzed the policy aspects that the coding system focused on, which can only be a partial account of the multidimensionality of policy change.

Behind the IPA scores, as with any type of coding, hide a number of key choices that influence the outcomes and their interpretation. Going back to the twin notions of policy density and policy intensity, it is important to remember that the IPA focuses on policy intensity. Does policy density offer a different outlook, or does it simply strengthen the IPA's findings? For example, policy density increased in the air quality and environment-industry subsectors, but was skewed toward soft, non-legislative instruments for the latter. Furthermore, while existing policies appear to have withstood calls for dismantling, there has been a sharp drop in the number of new policy proposals since the beginning of the Barroso II Commission, further heightened under Juncker (Kassim et al., 2017). This drop in the rate of proposals and the move towards the use of soft measures echoes Wilkinson et al.'s analysis that "it appears that that the EU's future environment policy is being driven in the general direction of 'less and looser"" (2005: 25). But crucially, this trend is also seen in other sectors: "this general reduction [of policy proposals] suggests a change in structural conditions under which legislation is produced rather than a marked reduction in particular policy domains" (Kassim et al., 2017: 665).

The IPA is one of many approaches to opening the black box of policy intensity. But does it look at the right elements? It is noteworthy that many of the dimensions measured by the IPA are not highly politicized in policy debates. For example, in ETS reform debates much more attention is paid to objectives than to monitoring. The IPA's focus on less-openly political issues could mean that intensity

\footnotetext{
${ }^{5}$ http://www.wwf.eu/?272571/EU-Nature-Directives-are-Fit-for-Purpose-study
} 
is increasing "despite the politics", or conversely that intensity may be decreasing in other more politicized policy elements - within the 'objectives' category; at instruments level etc. - without being included in the IPA coding scheme.

Finally, a key question of weighting remains. Because each IPA category is weighted equally, EU policies with no budget attached were scored as less intense than similar national policies, even though they have much greater trans-boundary scope. Similarly, the IPA makes an assumption that monitoring by an organization especially established for that purpose is by default more intense than monitoring by a more general body. However, such broad assumptions about the effectiveness and intensity of one type of generic policy approach over another are not neutral and need to be assessed in light of existing policy instruments and the implementation literature.

\section{Conclusion}

This chapter compared policy change across three subsectors of EU environmental policy: environment/industry, air quality, and climate and energy. It found that policy change occurred in all three subsectors. The direction of environmental policy across all three areas varied: from overall stasis for air quality policy (where policy intensity had dipped before the crisis but has since reached its early 1990s level), to limited increases for environment-industry policy (where intensity increased again after the crisis following years of stasis), and significant increases for climate and energy policy (although starting from a lower point). The few dismantling cases found appear akin to dismantling by default such as the EU failing to keep up with reinforced World Health Organization standards for ambient air - and dismantling by arena shifting - such as the EU granting Member States greater flexibility to meet their National Emissions Ceiling targets.

In relation to Hall's (1993) orders of policy change, our analysis largely found first-order (policy settings) and second-order (policy instruments) changes - for example changing the number of pollutants targeted and regulated levels. This is not surprising, given that the IPA measures policy intensity by examining changes in policy settings. It is therefore well suited to analyzing Hall's firstorder policy change and can also be used to study second-order change when analyzing a sufficiently 
broad number of policy instruments. However, the IPA does not directly address third-order change to the hierarchy of goals and policy paradigms. It is nevertheless noteworthy that we found key changes to legal instruments and not only policy instruments. The growing use of non-legislative instruments in the environment-industry subsector marks an apparent embrace of "new" environmental policy instruments and a move away from direct regulation. Critically, this appetite for non-regulatory instruments coupled with the sharp fall in environmental policy proposals (except in climate and energy) appears to show that a third-order change may be underway: a downgrading of environmental issues in the overall EU hierarchy of goals but also a profound change in how the Commission understands its role. Qualitative studies focusing on third-order change in EU environmental policy paradigms - in the direction suggested by Daigneault (2014) - could be a valuable addition to analysis of first- and secondorder change using the IPA.

Finally, further work is needed to analyze the reasons behind the apparent lack of success of calls to weaken environment policy intensity in the EU. Political actors that called for limits to environmental policy may have engaged in what Bauer and Knill (2014: 39) call "dismantling by symbolic action": highly visible calls for action that are deliberately not followed by policy change. Or they may have been in earnest but failed to gain sufficient support within the highly-consensual EU decision-making system. However, if environmental policy dismantling is prevented within the EU legislative system, it may be taking place through other strategies (Klyza and Sousa, 2013). These strategies could be focused on administrative appointments and priorities at EU level, partial implementation and enforcement of EU law in the Member States, or secondary legislation overseen by the European Commission. Further research on these and other topics will allow the scholarly community to build a more complete understanding of the impact of the economic crisis on environmental policy in the EU and beyond. 


\section{References}

Actal, National Normenkontrollrat, Regelradet, Committee Regulatory Policy, 2011. The End of the Commission's Action Programme for Reducing Administrative Burdens in the European Union - What Comes Next?

Barroso, J.M., 2013. José Manuel Durão Barroso. President of the European Commission. State of the Union Address 2013. European Parliament plenary session, Strasbourg.

Bauer, M.W., Knill, C., 2014. A Conceptual Framework for the Comparative Analysis of Policy Change: Measurement, Explanation and Strategies of Policy Dismantling. Journal of Comparative Policy Analysis: Research and Practice 16 (1), 28-44.

Bauer, M.W., Knill, C., 2012. Understanding Policy Dismantling: An Analytical Framework, In Bauer, M.W., Jordan, A., Green-Pedersen, C., Héritier, A. (Eds.), Dismantling Public Policy: Preferences, Strategies, and Effects. (Oxford: Oxford University Press), 30-56.

Boasson, E.L. \& Wettestad, J., 2013. EU Climate Policy: Industry, Policy Interaction and External Environment. Ashgate Publishing, Ltd.

Bürgin, A., 2015. National Binding Renewable Energy Targets for 2020, but Not for 2030 Anymore: Why the European Commission Developed from a Supporter to a Brakeman. Journal of European Public Policy 22 (5), 690-707.

Burns, C., Tobin, P., 2016. Ambition or Diminution? Analysing EU Environmental Policy over Time, in: ECPR PISA, 1-35.

Čavoški, A., 2015. A Post-austerity European Commission: No Role for Environmental Policy? Environmental Politics 24, 501-505.

Daigneault, P., 2013. Reassessing the Concept of Policy Paradigm: Aligning Ontology and Methodology in Policy Studies. Journal of European Public Policy, 21 (3), 453-469.

Delreux, T., Happaerts, S., 2016. The Evolution of EU Environmental Policy, in: Environmental Policy and Politics in the European Union. (Macmillan, London), 12-40.

European Commission, 2016. Commission Regulation (EU) 2016/427 of 10 March 2016 amending Regulation (EC) No 692/2008 as regards emissions from light passenger and commercial vehicles (Euro 6). Official Journal of the European Union 82, 1-98.

European Commission, 2015. Annex to the Commission Work Programme 2016: "No time for business as usual" $\operatorname{COM}(2015) 610$ final.

European Commission, 2014. Commission Work Programme 2015: A New Start ANNEX 1 $\operatorname{COM}(2014) 910$ final.

European Commission, 2013. Questions and answers on the EU Clean Air Policy Package.

European Council, 2008. Presidency Conclusions of the European Council - 11/12 December 2008.

European Council, 2014. Presidency Conclusions of the European Council - 23/24 October 2014.

European Environment Agency, 2013. Towards a green economy in Europe - EU environmental policy targets and objectives 2010-2050.

European Parliament, Council of the European Union, 2012. Directive 2012/33/EU of the European Parliament and of the Council.

European Parliament, Council of the European Union, 2000. Regulation (EC) No 1980/2000 of the European Parliament and of the Council, of 17 July 2000 on a revised Community eco-label award scheme, Official Journal of the European Communities. 
Falkner, G., 2016. The EU's Current Crisis and its Policy Effects: Research Design and Comparative Findings . Journal of European Integration 38 (3), 219-235.

Gravey, V., 2016. Does the European Union Have a Reverse Gear? Environmental Policy Dismantling, 1992-2014. University of East Anglia.

Gravey, V., 2014. Austerity at EU Level? How the Crisis Impacted EU Budget and Policies. Political Perspectives 8, 1-19.

Gravey, V., Jordan, A., 2016. Does the European Union Have a Reverse Gear? Policy Dismantling in a Hyperconsensual Polity. Journal of European Public Policy 23 (8), 1180-1198.

Green-Pedersen, C., 2004. The Dependent Variable Problem within the Study of Welfare State Retrenchment: Defining the Problem and Looking for Solutions. Journal of Comparative Policy Analysis: Research and Practice 6 (1), 3-14.

Haigh, N., 2016. EU Environmental Policy: Its Journey to Centre Stage. Routledge, Milton Park, Abingdon, Oxon; New York, NY.

Hey, C., 2005. EU Environmental Policies, A Short History, in: EEB (Ed.), EU Environmental Policy Handbook. pp. 17-30.

Jordan, A., Adelle, C. (Eds.), 2013. Environmental Policy in the EU: Actors, Institutions and Processes, 3rd ed. (Routledge, London; New York).

Jordan, A., Bauer, M.W., Green-Pedersen, C., 2013. Policy Dismantling. Journal of European Public Policy 20, 795-805.

Kassim, H., Connolly, S., Dehousse, R., Rozenberg, O., Bendjaballah, S., 2017. Managing the House: The Presidency, Agenda Control and Policy Activism in the European Commission. Journal of European Public Policy 24 (5), 653-674.

Klyza, C.M., Sousa, D.J., 2013. American Environmental Policy: Beyond Gridlock, 2nd ed. (MIT Press, Cambridge).

Nachmany, M., Fankhauser, S., Davidova, J., Kingsmill, N., Landesman, T., Roppongi, H., Schleifer, P., Setzer, J., Pavese, C., Sharman, A., Stolle Singleton, C., Sundaresan, J., Townshend, T., 2015. The 2015 Global Climate Legislation Study: A Review of Climate Change Legislation in 99 Countries.

Potočnik, J., 2012. Preface, in: Jordan, A., Adelle, C. (Eds.), Environmental Policy in the EU: Actors, Institutions and Processes. (Earthscan - Routledge, London), pp. xvii-xviii.

Schaffrin, A., Sewerin, S., Seubert, S., 2015. Toward a Comparative Measure of Climate Policy Output. Policy Studies Journal 43 (2), 257-282.

Schaffrin, A., Sewerin, S., Seubert, S., 2014. The Innovativeness of National Policy Portfolios Climate Policy Change in Austria, Germany, and the UK. Environmental Politics 23 (5), 860883.

Slominski, P., 2016. Energy and Climate Policy: Does the Competitiveness Narrative Prevail in Times of Crisis? Journal of European Integration 38 (3), 343-357.

Steinebach, Y., Knill, C., 2016. Still an Entrepreneur? The Changing Role of the European Commission in EU Environmental Policy-making. Journal of European Public Policy 24 (3), 429-446.

Van den Abeele, E., 2010. The European Union's Better Regulation Agenda. (European Union Trade Institute, Brussels).

Wall Street Journal, 2012. A New Industrial Policy for Europe (10/12/2012). Wall Street Journal.

Warleigh-Lack, A., 2010. Greening the European Union and Europe 2020 : A Response to Read, Prins and Pohoryles. Innovation: The European Journal of Social Science Research 23 (4), $327-332$. 
Wilkinson, D., Monkhouse, C., Herodes, M., Farmer, A., 2005. For Better or for Worse? The EU's 'Better Regulation' Agenda and the Environment. (IEEP, London). 